\title{
Effects of a Diamond Mine on Tundra-Breeding Birds
}

\author{
ADAM C. SMITH, ${ }^{1,2}$ JOHN A. VIRGL, ${ }^{3}$ DAMIAN PANAYI ${ }^{1}$ and ALLISON R. ARMSTRONG ${ }^{4}$
}

(Received 22 September 2004; accepted in revised form 15 March 2005)

\begin{abstract}
Breeding birds (songbirds, shorebirds, and ptarmigan) were surveyed at the Ekati Diamond Mine in Canada's Northwest Territories from 1996 through 2003. Surveys were conducted on permanent, 25 ha mine and control plots. Five metrics (relative density of individual species, relative density of all birds, species richness using rarefaction curves, and species diversity using two indices) were used to assess potential impacts up to a distance of $1 \mathrm{~km}$ from the mine. Six species were more common on mine plots, and three were more common on control plots. Species diversity was slightly higher on mine plots when measured with Fisher's alpha index. No other metrics suggested strong impacts. This study suggests that the mine has had a relatively limited impact on the upland breeding bird community within $1 \mathrm{~km}$ of the footprint but has provided habitat for at least one synanthropic bird species. Further monitoring of breeding birds on the tundra should include pre-development control data and demographic variables such as reproductive success and survival.
\end{abstract}

Key words: density, diversity, diamond mine, mining, monitoring, ptarmigan, richness, shorebirds, songbirds, tundra

RÉSUMÉ. De 1996 à 2003, on a étudié les oiseaux nicheurs (oiseaux chanteurs, oiseaux de rivage et lagopède) à la mine de diamants Ekati située dans les Territoires du Nord-Ouest au Canada. L'étude a été effectuée sur des parcelles permanentes de 25 ha, situées sur la mine et sur des sites témoins. On a utilisé 5 paramètres de mesure (densité relative de chaque espèce, densité relative de tous les oiseaux, richesse spécifique utilisant les courbes de raréfaction, et diversité spécifique utilisant deux indices) afin d'évaluer les retombées potentielles jusqu'à une distance de $1 \mathrm{~km}$ de la mine. Six espèces se retrouvaient plus communément sur les parcelles de la mine, et trois, sur les parcelles témoins. La diversité spécifique était légèrement plus grande sur les parcelles de la mine quand on les mesurait avec l'index alpha de Fisher. Aucun autre paramètre ne laissait croire qu'il y avait des retombées significatives. Cette étude suggère que la mine a eu un effet relativement limité sur la communauté terrestre des oiseaux nicheurs jusqu'à $1 \mathrm{~km}$ de son empreinte, mais qu'elle a fourni un habitat à au moins une espèce d'oiseau synanthrope. Des études ultérieures portant sur les oiseaux nicheurs dans la toundra devraient inclure des données de contrôle préalables à la mise en valeur et des variables démographiques telles que le succès de la reproduction et la survie.

Mots clés: densité, diversité, mine de diamants, exploitation minière, programme de contrôle, lagopède, richesse, oiseaux de rivage, oiseaux chanteurs, toundra

Traduit pour la revue Arctic par Nésida Loyer.

\section{INTRODUCTION}

Human activity can have major effects on the density of breeding birds and the species richness, diversity, and composition of bird communities (Rottenborn, 1999; Debinski and Holt, 2000; Thorington and Bowman, 2002; Hennings and Edge, 2003; Jokimaki and KaisanlahtiJokimaki, 2003). Many of these effects are associated with habitat alteration and fragmentation, but the presence of human development (roads and housing) and human activity (traffic and recreational activities) can also have significant impacts (Friesen et al., 1995; Reijnen et al., 1995; Riffell at al., 1996; Miller et al., 1998). To date, there has been little study of the impacts of human activity on tundra-nesting passerines and ptarmigan (but see Staniforth, 2002; Male, 2004). Studies on Alaska's North Slope have concentrated on loons, waterfowl, and shorebirds (Troy and Carpenter, 1990; National Research Council, 2003).

The Ekati Diamond Mine $\left(64^{\circ} 40^{\prime} \mathrm{N}, 110^{\circ} 40^{\prime} \mathrm{W}\right)$ is located in the central barrens of Canada's Northwest Territories in a region that has previously been exposed to limited human activity. Since 1998, permits have been granted for three other diamond mines in Canada's central Arctic.

Construction of the Ekati mine began in 1996, and the mine was in full production by October 1998. The regulatory processes leading up to the construction of the mine identified a number of Valued Ecosystem Components (VEC). These VEC, species or species groups that would be monitored during mine operations, included breeding birds: passerines, shorebirds, and ptarmigan (BHP, 1995). Raptors and waterfowl were studied within separate monitoring programs. Breeding birds were chosen as a

\footnotetext{
${ }^{1}$ Golder Associates Ltd., 4910 - 50th Ave., P.O. Box 1440, Yellowknife, Northwest Territories, Canada X1A 2P8

${ }^{2}$ Corresponding author: adam_c_smith@sympatico.ca

${ }^{3}$ Golder Associates Ltd., 145 1st Avenue North, Suite 200, Saskatoon, Saskatchewan, Canada S7K 1W6

${ }^{4}$ BHP Billiton Diamonds Inc., \#1102 4920 - 52nd Street, Yellowknife, Northwest Territories, Canada X1A 3T1

(C) The Arctic Institute of North America
} 
biological community that would be easy to survey and would provide high-quality, long-term information on species density and diversity, as well as on the overall health of the ecosystem (Furness and Greenwood, 1993; Canterbury et al., 2000).

Beyond the impacts of direct habitat loss from conversion of natural areas to human-dominated landscapes, habitat alteration and fragmentation have been identified as key factors in the effects of human development on avian communities (Friesen et al., 1995; Rottenborn, 1999; Trzcinski et al., 1999; Hennings and Edge, 2003). As of 2003, infrastructure at the Ekati mine occupied approximately 1800 ha. The loss of this habitat to breeding birds has had some impact on individuals that previously used this area for breeding or foraging. However, because relatively little human activity has occurred in the central barrens, habitat loss, alteration, and fragmentation are less likely to have a measurable affect at a community level. Developments in the Canadian Arctic are more likely to affect breeding bird communities through disturbance (noise and human activity), dust, and the introduction of non-native species (National Research Council, 2003).

Anthropogenic noise has been associated with reduced densities of some species of breeding birds along roads. The distances associated with noise effects vary with species but can extend up to $3000 \mathrm{~m}$, with the strongest effects generally observed within 100-200 m (Van der Zande et al., 1980; Reijnen et al., 1995, 1996; Canaday and Rivadeneyra, 2001). Noise at the Ekati mine is generated primarily by haul-truck and light truck traffic, heavy equipment operation, blasting, periodic aircraft overflights, and diesel-powered generators.

Dust from mining road traffic and blasting can affect vegetation surrounding the mine footprint. Recent research at the Ekati mine showed a negative correlation between dust deposition rates and moss cover within $100 \mathrm{~m}$ of major roads (Male, 2004). Increased concentrations of some metals have been recorded up to $5000 \mathrm{~m}$ from the mine footprint (BHP Billiton, 2002). In tundra environments, dust deposition along gravel roads can reduce photosynthesis and change the plant community through changes in soil $\mathrm{pH}$, earlier snowmelt, and increases in depth of the active layer (Spatt and Miller, 1981; Auerbach et al., 1997).

In addition to impacts from noise and dust, the presence of mine infrastructure (buildings, fuel tanks, gravel pads, waste rock piles, open pits) can introduce new nesting habitats. This effect has the potential to change avian communities by introducing or increasing the density of synanthropic bird species (Truett et al., 1994; Staniforth, 2002).

This study investigated the effects of mining activity at relatively broad spatial scales $(\sim 1000 \mathrm{~m})$ on the relative densities of individual species, relative density of all birds, and species diversity and richness of the breeding-bird community. The study design is sensitive to effects that extend at least $1000 \mathrm{~m}$ from the mine footprint, but it is relatively insensitive to finer-scale impacts, i.e., effects apparent only within $100 \mathrm{~m}$. Because the data have been collected annually for eight years, the design is also sensitive to effects of mining activity that may have accumulated over the monitoring period. These cumulative impacts may become apparent only after the disturbance has continued for some time (Harris, 1988).

\section{METHODS}

The study area is located within the Slave Geological Province of Canada's Northwest Territories, near the border with Nunavut (Fig. 1). Heath tundra represents the primary vegetation community type in the area and is composed of a heath mat (Ericaceae sp.) with low shrubs such as dwarf birch (Betula glandulosa), willow (Salix sp.), Labrador tea (Ledum decumbens), crowberry (Empetrum nigrum), and bearberry (Arctostaphylos alpina). Vegetation classes in this study follow those identified for the region by Matthews et al. (2001).

The peak reproductive season for birds begins during the first week of June and continues until approximately the third week of June. The most common species within the study area include Lapland longspur (Calcarius lapponicus), savannah sparrow (Passerculus sandwichensis), American tree sparrow (Spizella arborea), horned lark (Eremophila alpestris), and least sandpiper (Calidris minutilla).

Surveys were conducted within permanent 25 ha plots, classified as either mine or control. Each plot was divided into $100 \mathrm{~m}$ wide strip-transects that were surveyed by three observers walking abreast, covering the entire area of the plot. To limit the number of missed birds, the three observers walked parallel transects spaced approximately $33 \mathrm{~m}$ apart. This transect methodology was chosen because of the open nature of tundra that allowed observers to visually identify almost all birds present on the plot.

Estimates of absolute density from transect-count surveys require accurate and time-consuming measurements of distance from the transect line (Bibby et al., 2000; Buckland et al., 2001). To maximize the number of plots surveyed within the limited breeding season, we collected no data on distance. To limit potential variation due to habitat- or species-specific detection rates, we chose lots that contained similar structural habitat attributes (each plot was dominated by heath tundra and sedge wetland habitats). In addition, although there was some variation among years in observers, at least one of the three observers overlapped consecutive seasons, and within each year the same three observers surveyed both mine and control plots.

In addition to locating plots exclusively within heath tundra and sedge wetland vegetation communities to minimize differences due to habitat, we also selected plots so that an approximately equal area of each habitat was surveyed in mine and control sites. Surveys were 


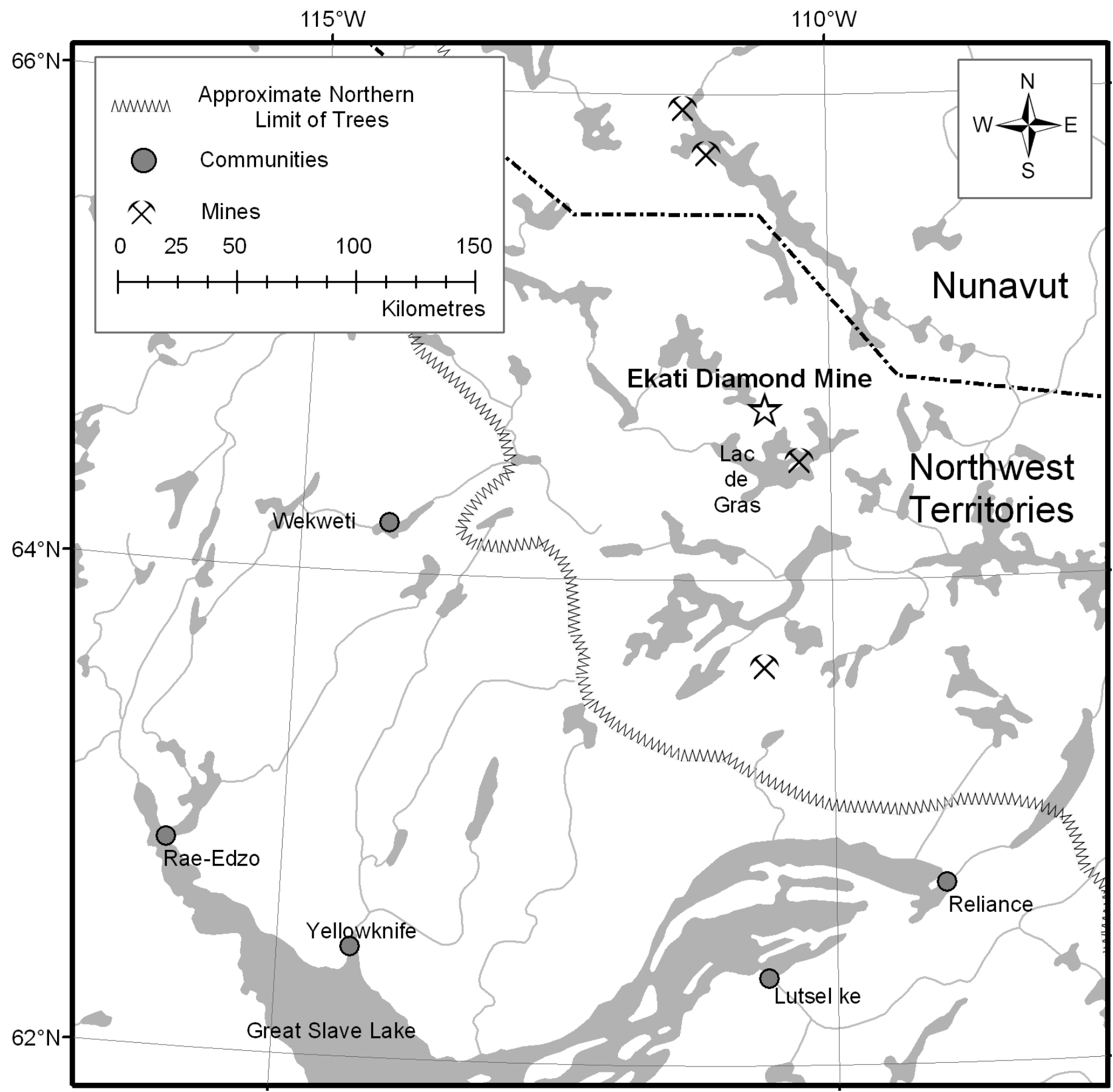

FIG. 1. Location of the Ekati Diamond Mine ${ }^{\mathrm{TM}}$ in the Northwest Territories, Canada.

conducted between the first and third weeks of June, during the morning hours (between sunrise and 10:00 am) when birds were actively singing. Mine and control plots were surveyed in a systematic order within each season and day to avoid biasing results due to phenology, weather, or time of day. Surveys were not conducted if wind speed was greater than $20 \mathrm{~km} / \mathrm{h}$, during periods of precipitation (rain or snow), or in extreme cold $\left(<2^{\circ} \mathrm{C}\right)$. Surveys were interrupted if noise or activity from the mine influenced the observers' ability to detect birds and resumed once the disturbance had ceased.
In 1996, six mine plots and five control plots were established within the study area. Additional plots were added over time as the mine expanded. In 2000, three plots initially classified as control plots were reclassified as mine plots after the construction of a new open-pit and associated road. Additional control plots were added to the study to parallel the growing number of mine plots. Over the eight years of the study, a mean of $8.6( \pm 1.1)$ mine plots and $8.9( \pm 0.9)$ control plots were surveyed each year (total for study: 140 plots). For all plots surveyed between 1996 and 2003, the mean distance to the mine footprint 


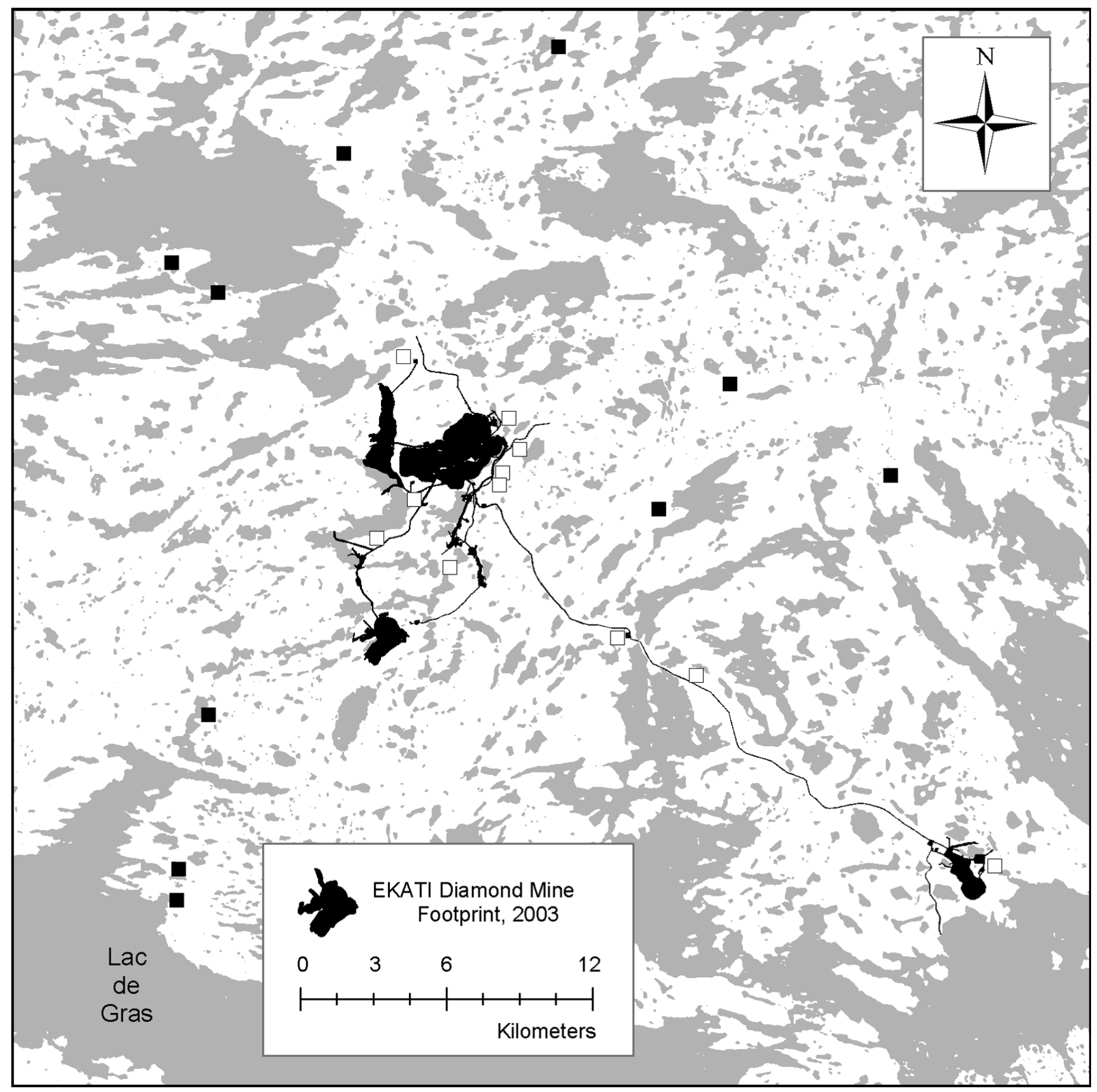

FIG. 2. Location of the Ekati Diamond Mine and plots established in the area for the study of upland breeding birds ( $\square$ indicates mine plots; $\square$ indicates control plots).

was $0.40 \mathrm{~km}$ (range: 0.02 to $0.80 \mathrm{~km}$ ) for mine plots and $9.9 \mathrm{~km}$ (range: 3.1 to $23.8 \mathrm{~km}$ ) for control plots (Fig. 2).

Birds were included in the analyses if they were located on the plot and gave evidence of territorial behaviour (such as territorial calls and displays or territorial disputes), leading behaviour (distraction), mating, nest building, incubation, or food carrying, or if the observers were otherwise able to confirm the existence of a nest. Birds seen or heard off the plot or not showing territorial behaviour (e.g., flyovers) were not included in the analyses.
Using data collected from 1996 through 2003, we performed two levels of analysis. The first (individual species analysis) examined the change in individual species densities from 1996 through 2003 on control and mine plots. Using a general linear model, we first analyzed the homogeneity of slopes to test for differences in temporal trends between mine and control plots, using year as a continuous variable. If no differences were detected in temporal trends, an analysis of covariance (ANCOVA) was then used to test for overall temporal trends (effects of year as a continuous 
variable) while accounting for possible differences between control and mine plots. Finally, if significant trends were present, the ANCOVA results were used to identify significant differences between mine and control plots. If no significant temporal trend was found, however, it was inappropriate to use the ANCOVA model to test for differences between control and mine plots. Therefore, we used a two-way Analysis of Variance (ANOVA, including the interaction term) to test for differences between control and mine plots while accounting for nonlinear annual variation (effects of year as a categorical variable).

The second analysis (community-level analysis) examined the density of all species in the upland bird community, as well as the species diversity and the species richness of the entire upland bird community. The density of all birds was tested to identify temporal trends and differences between mine and control plots. Data analysis for each plot and year followed the same procedure used for the individual species analyses, but in this case, we used a separate one-way ANOVA for each year to identify site effects because of a significant interaction between the effects of year and site. Observations of unidentified birds on the plots were included in overall density estimates but excluded from species diversity and richness estimates.

Species diversity has two components: the number of different species in the community (richness) and the relative abundance of each species in the community (evenness). Diversity was therefore analyzed using two indices: the Fisher's alpha index $(\alpha)$, which is more sensitive to richness, and the reciprocal of the Simpson's Index (1/D), which is more sensitive to evenness (Magurran, 1988). The two diversity indices were calculated separately for each sample plot and each year. Statistical analysis followed the same procedure used for the individual species analyses. Initial tests determined whether the indices displayed different temporal trends between control and mine plots (homogeneity of slopes), and subsequent tests identified significant linear temporal trends across years (ANCOVA) and differences between control and mine plots, using either ANCOVA (significant temporal trend) or ANOVA (no significant trend).

To examine species richness more closely, we generated rarefaction curves to compare the number of observed species with the number of individuals sampled for each year and site, using a bootstrapping or rarefaction technique (Magurran, 1988; Gotelli and Colwell, 2001). Using these rarefaction curves, we then standardized values of species richness to 350 observed individuals for each year and site. Although this decision was partially arbitrary, the value of 350 individuals was chosen as a compromise between a value large enough to capture differences in the rarefaction curves among years and sites and one small enough to include most years. In 1997, logistical problems limited sampling, and the number of observed individuals did not reach a total of 350 on either mine plots or control plots. Therefore, data from 1997 were not used in the analysis. The analysis of the standardized values followed the same procedure as the previous analyses with one exception. Because the calculation of the standardized species richness generates only one value for each year and plot type, a one-way ANOVA was used to identify differences in species richness between control plots and mine plots.

A second method for investigating the effects of site on species richness involved pooling data from all years (including 1997) and computing one species rarefaction curve for each site. The significance of the differences between the sites was then assessed by comparing the curves and their associated $95 \%$ confidence limits.

The level of statistical significance was not adjusted for the number of statistical tests conducted (i.e., probability of Type I error). Adjusting for the number of tests would have resulted in an extremely conservative level of significance and increased the chance of not detecting a statistically significant effect (i.e., increased probability of Type II error). For our purpose of analyzing the potential effects of mining activity, we decided that an increased probability of Type I error was preferable to an increased probability of Type II error.

All statistical analyses were conducting using JMP version 5.0 (SAS Institute Inc., Cary, North Carolina). Species richness analyses were conducted using EstimateS version 6.0b1 (available at http://viceroy.eeb.uconn.edu/ EstimateS).

\section{RESULTS}

\section{Individual Species-Level Effects}

From 1996 through 2003, we identified 29 species as breeding in upland areas within the Ekati mine study area. Twenty-two species occurred on both control and mine plots. Three species (blackpoll warbler Dendroica striata, pectoral sandpiper Calidris melanotos, and yellow-rumped warbler Dendroica coronata) were found only on control plots, and four species (Eastern kingbird Tyrannus tyrannus, lesser yellowlegs Tringaflavipes, spotted sandpiper Actitis macularia, and white-rumped sandpiper Calidris fuscicollis) were found only on mine plots. Each of these seven species was observed in only one or two incidences over the eight-year monitoring period.

Of the 22 species detected at both plot types between 1996 and 2003, none showed a significant difference in trend over time between control and mine plots $(\mathrm{F}<2.99$, $p>0.09$, Table 1). Only three species showed statistically significant temporal trends in density across both plot types (Table 1). Willow ptarmigan (Lagopus lagopus) density in the study area decreased from 1996 through $2003\left(\mathrm{~F}_{1,137}=24.5, \mathrm{R}^{2}=0.16, p<0.01\right)$ and the densities of the Wilson's snipe (Gallinago delicata, $\mathrm{F}_{1,137}=8.71, \mathrm{R}^{2}=$ $0.06, p<0.01$ ) and the least sandpiper (Calidris minutilla, $\left.\mathrm{F}_{1,137}=8.23, \mathrm{R}^{2}=0.07, p<0.01\right)$ increased over the same period (Table 1). The decrease in willow ptarmigan across 
TABLE 1. Significance of linear, temporal trends in individual species density from 1996 to 2003 and differences in temporal trends between control and mine plots. Bold type indicates species that showed statistically significant year effects.

\begin{tabular}{|c|c|c|c|}
\hline Species & $\begin{array}{c}p \\
\text { (Homogeneity of Slopes Between Sites - Effect of Site) }\end{array}$ & $\begin{array}{c}\text { Slope } \\
\text { (Across Years) }\end{array}$ & $\begin{array}{c}p \\
\text { (Effect of Year) }\end{array}$ \\
\hline Willow ptarmigan (Lagopus lagopus) & 0.43 & -0.30 & $<0.01$ \\
\hline Rock ptarmigan (Lagopus muta) & 0.63 & -0.03 & 0.35 \\
\hline American golden plover (Pluvialis dominica) & 0.11 & -0.06 & 0.14 \\
\hline Semi-palmated plover (Charadrius semipalmatus) & 0.79 & -0.01 & 0.82 \\
\hline Semi-palmated sandpiper (Calidris pusilla) & 0.09 & +0.10 & 0.14 \\
\hline Least sandpiper (Calidris minutilla) & 0.41 & +0.44 & $<0.01$ \\
\hline Baird's sandpiper (Calidris bairdii) & 0.65 & -0.01 & 0.81 \\
\hline Stilt sandpiper (Calidris himantopus) & 0.35 & +0.02 & 0.62 \\
\hline Wilson's snipe (Gallinago delicata) & 0.91 & +0.05 & $<0.01$ \\
\hline Red-necked phalarope (Phalaropus lobatus) & 0.11 & +0.13 & 0.10 \\
\hline Horned lark (Eremophila alpestris) & 0.47 & +0.12 & 0.13 \\
\hline Gray-cheeked thrush (Catharus minimus) & 0.75 & +0.04 & 0.38 \\
\hline American robin (Turdus migratorius) & 0.77 & -0.02 & 0.48 \\
\hline American pipit (Anthus rubescens) & 0.33 & +0.04 & 0.23 \\
\hline Yellow warbler (Dendroica petechia) & 0.38 & +0.04 & 0.12 \\
\hline American tree sparrow (Spizella arborea) & 0.15 & +0.18 & 0.44 \\
\hline Savannah sparrow (Passerculus sandwichensis) & 0.93 & +0.24 & 0.45 \\
\hline Harris’ sparrow (Zonotrichia querula) & 0.42 & +0.12 & 0.36 \\
\hline White-crowned sparrow (Zonotrichia leucophrys) & 0.32 & +0.03 & 0.60 \\
\hline Lapland longspur (Calcarius lapponicus) & 0.50 & -0.36 & 0.51 \\
\hline Common redpoll (Carduelis flammea) & 0.43 & -0.03 & 0.65 \\
\hline Hoary redpoll (Carduelis hornemanni) & 0.28 & -0.06 & 0.27 \\
\hline
\end{tabular}

${ }^{1} \alpha$ values were not adjusted for multiple comparisons. See text for explanation.

all plots parallels the trends observed in Christmas bird counts for Yellowknife and Norman Wells (National Audubon Society, 2004) and is likely a reflection of shortterm, regional population cycles.

There were no significant interactions between the effects of year and site for 19 of the 22 species present on both control and mine plots $(\mathrm{F}<1.48, p>0.18)$. Three species (Lapland longspur, American tree sparrow, and savannah sparrow) showed significant interactions ( $\mathrm{F}>$ $2.17, p<0.04)$, and the effect of site on the densities of these species was therefore examined using separate oneway ANOVA for each year.

The densities of nine species of upland birds were significantly different between control and mine plots. Mine plots showed significantly higher densities of American robins Turdus migratorius, horned larks, rock ptarmigan Lagopus mutus, semipalmated plovers Charadrius semipalmatus, and white-crowned sparrows Zonotrichia leucophrys (Table 2), as well as Lapland longspurs, in $1999\left(\mathrm{~F}_{1,9}=18.87, p<0.01\right)$. Control plots showed significantly higher densities of hoary redpolls (Carduelis hornemanni) and American tree sparrows in 1996 and $1999(\mathrm{~F}>4.86, p<0.05)$ and savannah sparrows in 1996 , 1998 , and $2000(\mathrm{~F}>5.83, p<0.03)$. In all other years, the densities of Lapland longspurs, American tree sparrows, and savannah sparrows were not significantly different between mine and control plots $(\mathrm{F}<3.99, p>0.08)$.

\section{Community-Level Effects}

The ANCOVA indicated that there was no significant difference between the temporal trends in overall relative density of control plots and mine plots $\left(\mathrm{F}_{1,136}=0.33\right.$, $p>0.50)$ and no significant overall temporal trend $\left(\mathrm{F}_{1,137}=\right.$ $0.29, p>0.50)$. The ANOVA showed significant interaction between the effects of year and site, indicating that interannual differences in relative density of all upland breeding birds were not consistent between control and mine plots $\left(\mathrm{F}_{7,124}=2.09, p=0.05\right.$, Table 3$)$. A separate analysis by year and site was therefore performed. Results indicated that density changed significantly from year to year on both control and mine plots $(\mathrm{F}>5.12, p<0.01)$. Significant year-to-year variation in density was largely related to lower values obtained in 1997 relative to other years (Table 3 ). The difference in mean density between control and mine plots was not statistically significant within any given year $(\mathrm{F}<5.12, p>0.09$, Table 3$)$.

No significant interaction between the effects of year and site on species diversity was found using Fisher's $\alpha$, which is more sensitive to richness, indicating similar temporal trends for mine plots and control plots $\left(\mathrm{F}_{1,136}=\right.$ $0.02, p>0.50)$. Fisher's $\alpha$ also showed no significant temporal trend over time $\left(\mathrm{F}_{1,136}=0.01, p>0.50\right)$. When accounting for the effect of year as a categorical variable, the difference in Fisher's $\alpha$ between mine and control plots approached significance $\left(\mathrm{F}_{1,131}=3.85, p=0.05\right.$, Table 4$)$. Mean annual values of Fisher's $\alpha$ were higher on mine plots in all years except 1996 and 1999. There was no significant difference among years in Fisher's $\alpha\left(\mathrm{F}_{7,131}=\right.$ $1.02, p>0.10)$.

When analyzed with an index that is more sensitive to evenness, temporal trends in species diversity (1/D) were similar between control and mine plots $\left(\mathrm{F}_{1,136}=2.10\right.$, $p>0.10)$. Over time, $1 / \mathrm{D}$ showed a slightly increasing 
TABLE 2. Mean ( $\pm \mathrm{SE}$ ) relative density (individuals $/ 0.25 \mathrm{~km}^{2}$ ) of upland breeding bird species from 1996 to 2003 on control and mine plots. ${ }^{1}$ Bold type indicates species that showed statistically significant year effects.

\begin{tabular}{lccc}
\hline \hline Species & Control & Mine & $\begin{array}{c}p \\
\text { (ANOVA, } \\
\text { Effect of Site) }\end{array}$ \\
\hline Willow ptarmigan) & $1.6 \pm 0.2$ & $1.1 \pm 0.2$ & $0.32^{2}$ \\
Rock ptarmigan & $\mathbf{0 . 4} \pm \mathbf{0 . 0 7}$ & $\mathbf{1 . 0} \pm \mathbf{0 . 1}$ & $<\mathbf{0 . 0 1}$ \\
American golden plover & $0.5 \pm 0.1$ & $0.5 \pm 0.1$ & 0.27 \\
Semi-palmated plover & $\mathbf{0 . 0 2} \pm \mathbf{0 . 0 2}$ & $\mathbf{0 . 4} \pm \mathbf{0 . 1}$ & $<\mathbf{0 . 0 1}$ \\
Semi-palmated sandpiper & $0.3 \pm 0.08$ & $0.8 \pm 0.3$ & 0.24 \\
Least sandpiper & $2.1 \pm 0.3$ & $3.1 \pm 0.6$ & $0.26^{2}$ \\
Baird's sandpiper & $0.2 \pm 0.06$ & $0.1 \pm 0.06$ & 0.28 \\
Stilt sandpiper & $0.5 \pm 0.2$ & $0.4 \pm 0.1$ & 0.43 \\
Wilson's snipe & $0.2 \pm 0.07$ & $0.1 \pm 0.05$ & $0.43^{2}$ \\
Red-necked phalarope & $0.3 \pm 0.09$ & $0.9 \pm 0.4$ & 0.26 \\
Horned lark & $\mathbf{1 . 6} \pm \mathbf{0 . 2}$ & $\mathbf{2 . 8} \pm \mathbf{0 . 3}$ & $\mathbf{0 . 0 1}$ \\
Gray-cheeked thrush & $0.6 \pm 0.2$ & $0.4 \pm 0.1$ & 0.11 \\
American robin & $\mathbf{0 . 1} \pm \mathbf{0 . 0 6}$ & $\mathbf{0 . 4} \pm \mathbf{0 . 1}$ & $\mathbf{0 . 0 1}$ \\
American pipit & $0.4 \pm 0.1$ & $0.5 \pm 0.1$ & 0.96 \\
Yellow warbler & $0.3 \pm 0.1$ & $0.2 \pm 0.07$ & 0.13 \\
American tree sparrow & $8.6 \pm 0.9$ & $6.0 \pm 0.5$ & -3 \\
Savannah sparrow & $11.3 \pm 1.2$ & $6.9 \pm 0.8$ & - \\
Harris' sparrow & $2.7 \pm 0.4$ & $3.3 \pm 0.4$ & 0.87 \\
White-crowned sparrow & $\mathbf{0 . 6} \pm \mathbf{0 . 2}$ & $\mathbf{1 . 4} \pm \mathbf{0 . 2}$ & $\mathbf{0 . 0 3}$ \\
Lapland longspur & $20.7 \pm 1.6$ & $26.4 \pm 1.8$ & - \\
Common redpoll & $0.6 \pm 0.2$ & $0.4 \pm 0.09$ & 0.07 \\
Hoary redpoll & $\mathbf{0 . 7} \pm \mathbf{0 . 2}$ & $\mathbf{0 . 3} \pm \mathbf{0 . 1}$ & $\mathbf{0 . 0 3}$ \\
\hline \hline
\end{tabular}

${ }^{1}$ No statistical analyses were conducted on species unique to control or mine plots.

${ }^{2}$ Tested using ANCOVA because of a statistically significant linear, temporal trend.

${ }^{3}$ The indication "_" means that testing was done with separate one-way ANOVA for site and year because of significant interaction. See text for results.

TABLE 3. Mean ( $\pm \mathrm{SE}$ ) density (individuals $/ 0.25 \mathrm{~km}^{2}$ ) of upland breeding birds on control and mine plots ${ }^{1}$ from 1996 to 2003.

\begin{tabular}{lccc}
\hline \hline Year & Control & Mine & $p$ \\
\hline 1996 & $87.0 \pm 12.7(5)$ & $67.1 \pm 4.5(6)$ & 0.15 \\
1997 & $18.5 \pm 3.2(12)$ & $12.4 \pm 1.3(5)$ & 0.25 \\
1998 & $73.8 \pm 8.7(12)$ & $54.4 \pm 4.1(9)$ & 0.09 \\
1999 & $80.3 \pm 15.1(6)$ & $109.5 \pm 10.1(4)$ & 0.19 \\
2000 & $82.0 \pm 3.6(8)$ & $69.8 \pm 5.4(12)$ & 0.11 \\
2001 & $41.4 \pm 4.7(9)$ & $49.4 \pm 8.4(11)$ & 0.45 \\
2002 & $45.1 \pm 4.3(9)$ & $65.1 \pm 12.5(11)$ & 0.18 \\
2003 & $60.2 \pm 5.6(10)$ & $60.2 \pm 9.4(11)$ & 1.00 \\
Mean & $57.1 \pm 3.6$ & $60.2 \pm 3.7$ & \\
\hline
\end{tabular}

${ }^{1}$ Number in parentheses indicates number of plots surveyed.

trend that approached statistical significance $\left(\mathrm{F}_{1,137}=3.86\right.$, $\mathrm{R}^{2}=0.04, p=0.05$, Fig. 3). The ANCOVA also showed that $1 / \mathrm{D}$ was similar between control plots and mine plots $\left(\mathrm{F}_{1,137}=0.57, p>0.10\right.$, Table 5).

When species richness was standardized for a common number of observed individuals, there was no significant difference in the temporal trends in species richness between control and mine plots $\left(\mathrm{F}_{1,13}=0.03, p>0.50\right.$, Table 6). Species richness also showed no significant temporal trend
TABLE 4. Mean ( \pm SE) species diversity (Fisher's $\alpha$ ) of upland breeding birds on control and mine plots ${ }^{1}$ from 1996 to 2003.

\begin{tabular}{lcrrr}
\hline \hline Year & \multicolumn{2}{c}{ Control } & \multicolumn{2}{c}{ Mine } \\
\hline 1996 & $3.46 \pm 0.44(5)$ & $3.24 \pm 0.36 \quad(6)$ \\
1997 & $2.41 \pm 0.37(12)$ & $3.65 \pm 0.73(5)$ \\
1998 & $2.82 \pm 0.33(12)$ & $3.28 \pm 0.28(9)$ \\
1999 & $4.43 \pm 1.27(6)$ & $2.90 \pm 0.60(4)$ \\
2000 & $3.12 \pm 0.28(8)$ & $3.83 \pm 0.30(12)$ \\
2001 & $2.61 \pm 0.29(9)$ & $3.24 \pm 0.27(11)$ \\
2002 & $2.83 \pm 0.35(9)$ & $3.19 \pm 0.29(11)$ \\
2003 & $2.88 \pm 0.31(10)$ & $3.50 \pm 0.41(11)$ \\
Pooled (Weighted) Mean & $2.95 \pm 0.15$ & $3.39 \pm 0.15$ \\
\hline
\end{tabular}

${ }^{1}$ Number in parentheses indicates number of plots surveyed.

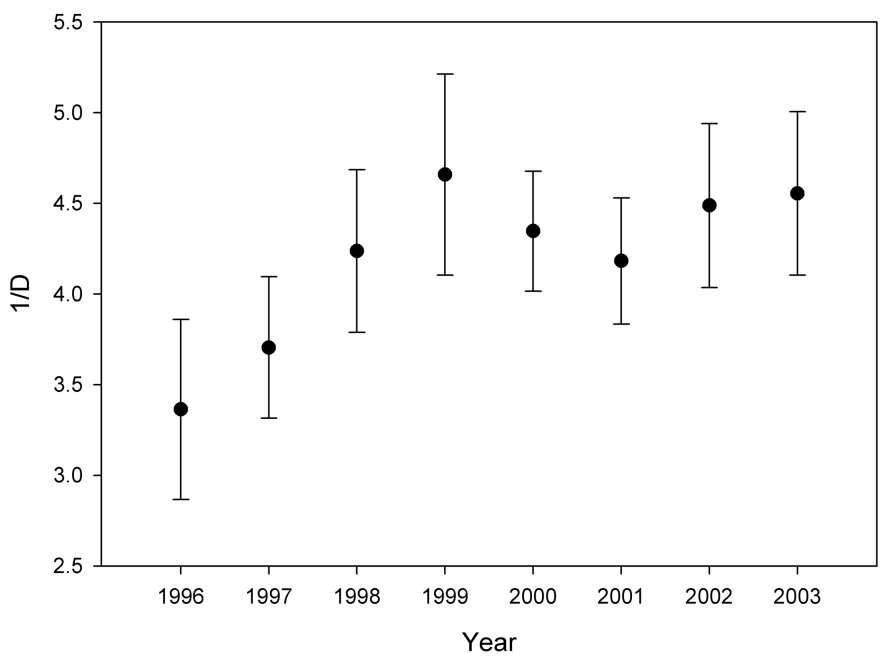

FIG. 3. Mean annual species diversity (1/D) of upland breeding birds, for all plots, 1996-2003 (error bars indicate SE).

from 1996 through $2003\left(\mathrm{~F}_{1,13}=2.11, p>0.10\right)$. Using an ANOVA, overall species richness was similar between control and mine plots $\left(\mathrm{F}_{1,13}=1.24, p>0.10\right)$. In the related analysis, when data from all years were pooled and a single species-accumulation curve was created for each plot type, the curve for mine plots appeared to approach a slightly higher asymptote than that for control plots, but the $95 \%$ CI overlapped (Fig. 4).

\section{DISCUSSION}

Overall, the monitoring data collected around the mine from 1996 through 2003 suggest that the mining activity has had some effect on breeding birds. The mine plots showed changes in the relative densities of nine individual species and slightly higher species diversity when analyzed with an index more sensitive to richness than to evenness. The remainder of the analyses at both individual species and community levels indicated that values and trends were similar on mine and control plots.

The differences in individual species densities may be directly related to mining disturbance or indirectly related to mining through changes in habitat from mining activity. 
TABLE 5. Mean ( \pm SE) species diversity (1/D) of upland breeding birds on control and mine plots ${ }^{1}$ from1996 to 2003.

\begin{tabular}{lccc}
\hline \hline Year & Control & Mine \\
\hline 1996 & $4.61 \pm 0.78(5)$ & $2.33 \pm 0.16$ & $(6)$ \\
1997 & $3.75 \pm 0.42(12)$ & $3.59 \pm 0.94$ & $(5)$ \\
1998 & $4.10 \pm 0.54(12)$ & $4.42 \pm 0.79(9)$ \\
1999 & $5.58 \pm 0.66(6)$ & $3.27 \pm 0.37(4)$ \\
2000 & $4.49 \pm 0.66(8)$ & $4.25 \pm 0.36(12)$ \\
2001 & $3.86 \pm 0.62(9)$ & $4.45 \pm 0.39(11)$ \\
2002 & $4.37 \pm 0.68(9)$ & $4.59 \pm 0.64(11)$ \\
2003 & $4.51 \pm 0.66(10)$ & $4.59 \pm 0.65(11)$ \\
Pooled (Weighted) Mean & $4.31 \pm 0.22$ & $4.14 \pm 0.22$ \\
\hline \hline
\end{tabular}

${ }^{1}$ Number in parentheses indicates number of plots surveyed.

American robins were observed nesting on mine infrastructure, and their greater relative density at mine plots is likely related to an increased availability of suitable nesting habitat. Five of the six species (all but rock ptarmigan) that were more abundant at mine plots also increased in response to urbanization effects at an Arctic community (Staniforth, 2002). Although the differences in the relative densities of individual species were not reflected in similar differences in overall relative density (Troy and Carpenter, 1990; Reijnen et al., 1995; Canaday and Rivadeneyra, 2001), species-specific responses likely confound this result. Because comparable data were not collected before construction of the mine began, suitable temporal control data are unavailable, and it is possible that these mine effects have been confounded by unrelated environmental factors.

The slightly higher levels of diversity (Fisher's $\alpha$ ) near the mine may be attributed to a number of factors. The mine infrastructure (buildings, roads, rock-piles, gravel pits) creates nesting habitat for some species that are otherwise less common in the surrounding landscape (e.g., American robin). In addition, dust deposition from industrial activities in the Arctic has been associated with earlier snowmelt around infrastructure (Walker and Everett, 1987). We did not measure snowmelt at the mine, but an early snowmelt effect, if it is occurring, could have produced an amelioration of local or micro-climatic conditions that attracted some species, leading to the observed effects on diversity.

Disturbance from anthropogenic noise has also been correlated with reduced densities of breeding birds (Reijnen et al., 1995; Canaday and Rivadeneyra, 2001). We found no evidence of reduced overall densities of birds adjacent to the mine site. It is possible that the intensity of the noise produced by the mine is not sufficient to cause major disturbances. Other studies have been conducted along highways with much higher traffic frequency than in our study area $(\sim 50,000$ vehicles/day vs. $\sim 200$ vehicles/day at Ekati). In addition, noise disturbances from human activity are generally strongest over short distances (up to $\sim 300 \mathrm{~m}$, Reijnen et al., 1995; Canaday and Rivadeneyra, 2001). Almost all of the mine plots in this study extended more than $300 \mathrm{~m}$ (some up to $1000 \mathrm{~m}$ ) from the mine footprint
TABLE 6. Adjusted species richness (species/350 individuals) of upland breeding birds on control and mine plots ${ }^{1}$ from 1996 to 2003. Data from 1997, when logistical problems limited sampling, were not included because the total number of individuals observed was too low to be comparable.

\begin{tabular}{lrrrr}
\hline \hline Year & \multicolumn{2}{c}{ Control } & \multicolumn{2}{c}{ Mine } \\
\hline 1996 & 18.67 & $(5)$ & 17.72 & $(6)$ \\
1998 & 17.07 & $(12)$ & 17.27 & $(9)$ \\
1999 & 19.43 & $(6)$ & 16.45 & $(4)$ \\
2000 & 17.67 & $(8)$ & 19.45 & $(12)$ \\
2001 & 19.88 & $(9)$ & 18.93 & $(11)$ \\
2002 & 20.44 & $(9)$ & 18.00 & $(11)$ \\
2003 & 18.24 & $(10)$ & 18.84 & $(11)$ \\
Pooled (Weighted) Mean (土 1SE) & $18.77 \pm 0.46$ & $18.09 \pm 0.40$ \\
\hline \hline
\end{tabular}

${ }^{1}$ Number in parentheses indicates number of plots surveyed.

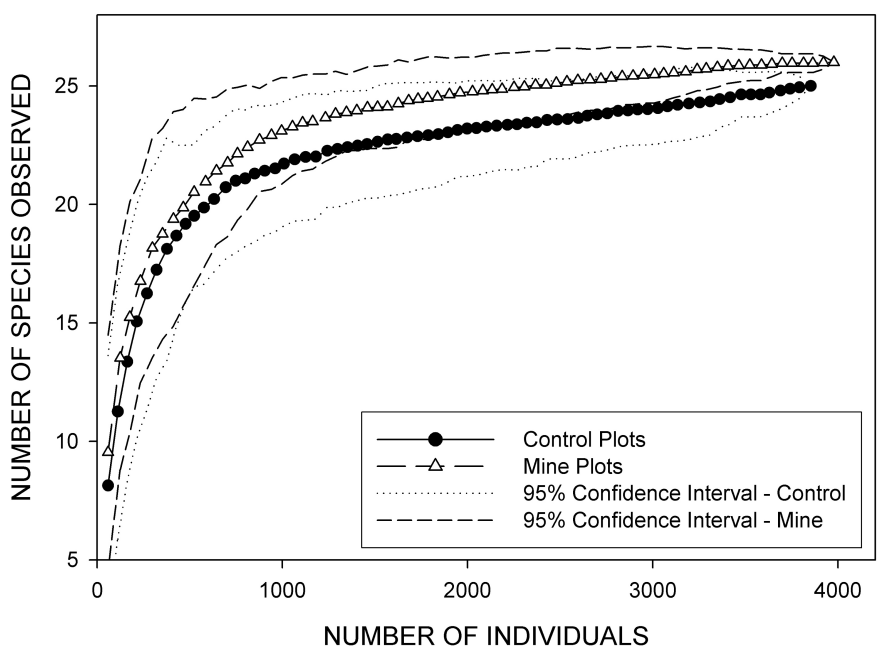

FIG. 4. Species accumulation curves for upland breeding birds on control and mine plots, 1996-2003.

and would therefore be relatively insensitive to effects operating within a few hundred metres.

It is also possible that mining activity may affect other aspects of avian biology independently of relative density or community measures. Measures of density can be misleading indicators of anthropogenic impacts if they are inversely related to survival or reproductive success (Van Horne, 1983). Related research at the mine has shown that the nest success of Lapland longspurs was unaffected within approximately $300 \mathrm{~m}$ of major haul roads (Male, 2004). Studies of the reproductive success and survival of other tundra species are an important complement to studies of density and community diversity. Monitoring efforts should ensure that developments do not create ecological traps, within which population density remains high but survival or reproductive success is reduced (Bock and Jones, 2004).

Landscape-scale processes may further explain why this study failed to detect stronger effects around the mine (Boulinier et al., 2001). Much of impact on species richness and diversity in forested environments (Blair, 1996; 
Rottenborn, 1999; Hennings and Edge, 2003) has been attributed to changes at a landscape level (Flather, 1996; Trzcinski et al., 1999; Debinski and Holt, 2000). Although the surrounding region is not entirely pristine (there are a number of outfitting and mineral exploration camps and another diamond mine within $50 \mathrm{~km}$ ), the mine is situated within a largely intact matrix of undisturbed tundra, interrupted by relatively few unconnected point sources of human activity. Development in the region may not have reached a critical threshold to affect bird communities on a landscape scale.

Although three species showed significant temporal trends in density within the region, we found no indication of differences in temporal trends between mine plots and control plots. This result suggests that any temporal, cumulative effects to date have been minimal. However, lag times and thresholds for impacts from human activities are largely unknown (Riffell et al., 1996). Dust deposition from mine activities (blasting and road traffic) can lead to changes in vegetation cover that are likely to accumulate over time (Walker and Everett, 1987; Auerbach et al., 1997). At fine spatial scales, dust deposition has been correlated with reduced levels of moss cover near Ekati roads (Male, 2004). Although to date these changes have been identified only at relatively fine spatial scales $(\sim 100 \mathrm{~m})$, they may become more pronounced over time (National Research Council, 2003). This potential reinforces the importance of continued monitoring of the bird community adjacent to the mine.

To date, the Ekati mine has had some effects on individual species densities and has led to a small increase in species diversity adjacent to the mine. However, other measures have not shown strong mine-related impacts. The relatively minor impacts observed to date around the Ekati mine are encouraging, although the potential remains for stronger effects of the mine at spatial scales finer than could be detected in this study and for undetected effects to accumulate over time. As development expands in the region, future studies and monitoring programs should focus efforts on collecting temporal and spatial control data that can be directly compared to monitoring data, as well as data on demographic parameters that may be sensitive to disturbance, such as reproductive success and survival.

\section{ACKNOWLEDGEMENTS}

Funding for this work was provided by BHP Billiton Diamonds Inc., Yellowknife, NT. Field assistance was provided by K. Algona, J. Bastedo, M. Beauregard, J. Bolt, T. Calverly, R. Eskelson, D. Mazerolle, S. Moore, C. Pilon, C. Zoe-Chocolate, and other staff of the Ekati mine. Logistical support was provided by C. Hanks, J. Witteman, H. Newton, N. Lee, P. Hogg, and the staff of Great Slave Helicopters. The authors would like to thank C. Machtans for constructive suggestions on an earlier draft of the manuscript.

\section{REFERENCES}

AUERBACH, N.A., WALKER, M.D., and WALKER, D.A. 1997. Effects of roadside disturbance on substrate and vegetation properties in arctic tundra. Ecological Applications 7:218-235.

BHP. 1995. Environmental impact statement for the BHP Diamonds Project. Prepared by Rescan Environmental Services Ltd. for BHP Minerals Inc., Yellowknife, NT and Vancouver, BC. Available at BHP Billiton Diamonds Inc., \#1102, 4920 52nd Street, Yellowknife, Northwest Territories X1A 3T1.

BHP BILLITON. 2002. EKATI Diamond Mine ${ }^{\mathrm{TM}}$ air quality monitoring report, 2001. Prepared by MDA Consulting Ltd. for BHP Billiton Diamonds Inc. Yellowknife, NT. Available at BHP Billiton Diamonds Inc., \#1102, 4920 52nd Street, Yellowknife, Northwest Territories X1A 3T1.

BIBBY, C.J., BURGESS, N.D., HILL, D.A., and MUSTOE, S. 2000. Bird census techniques, 2nd ed. London: Academic Press.

BLAIR, R.B. 1996. Land use and avian species diversity along an urban gradient. Ecological Applications 6:506-519.

BOCK, C.E., and JONES, Z.F. 2004. Avian habitat evaluation: Should counting birds count? Frontiers in Ecology and the Environment 2:403-410.

BOULINIER, T., NICHOLS, J.D., HINES, J.E., SAUER, J.R., FLATHER, C.H., and POLLOCK, K.H. 2001. Forest fragmentation and bird community dynamics: Inference at regional scales. Ecology 82:1159-1169.

BUCKLAND, S.T., ANDERSON, D.R., BURNHAM, K.P., LAAKE, J.L., BORCHERS, D.L., and THOMAS, L. 2001. Introduction to distance sampling: Estimating abundance of biological populations. Oxford: Oxford University Press.

CANADAY, C., and RIVADENEYRA, J. 2001. Initial effects of a petroleum operation on Amazonian birds: Terrestrial insectivores retreat. Biodiversity and Conservation 10:567-595.

CANTERBURY, G.E., MARTIN, T.E., PETIT, D.R., PETIT, L.J., and BRADFORD, D.F. 2000. Bird communities and habitat as ecological indicators of forest condition in regional monitoring. Conservation Biology 14:544-558.

DEBINSKI, D.M., and HOLT, R.D. 2000. A survey and overview of habitat fragmentation experiments. Conservation Biology 14:342-355.

FLATHER, C.H. 1996. Fitting species-accumulation functions and assessing regional land use impacts on avian diversity. Journal of Biogeography 23:155-168.

FRIESEN, L.E., EAGLES, P.F.J., and MacKAY, R.J. 1995. Effects of residential development on forest-dwelling neotropical migrant songbirds. Conservation Biology 9:1408-1414.

FURNESS, R.W., and GREENWOOD, J.J.D. 1993. Birds as monitors of environmental change. London: Chapman and Hall.

GOTELLI, N., and COLWELL, R.K. 2001. Quantifying biodiversity: Procedures and pitfalls in the measurement and comparison of species richness. Ecology Letters 4:379-391.

HARRIS, L.D. 1988. The nature of cumulative impacts on biotic diversity of wetland vertebrates. Environmental Management 12:675-693.

HENNINGS, L.A., and EDGE, D.W. 2003. Riparian bird community structure in Portland Oregon: Habitat, urbanization, and spatial scale patterns. The Condor 105:288-302. 
JOKIMAKI, J., and KAISANLAHTI-JOKIMAKI, M. 2003. Spatial similarity of urban bird communities: A multiscale approach. Journal of Biogeography 30:1183-1193.

MAGURRAN, A.E. 1988. Ecological diversity and its measurement. Princeton, New Jersey: Princeton University Press.

MALE, S.K. 2004. Reproductive ecology of the Lapland longspur (Calcarius lapponicus) near a diamond mine. M.Sc. thesis, Trent University, Peterborough, Ontario.

MATTHEWS, S., EPP, H., and SMITH, G. 2001. Vegetation classification for the West Kitikmeot/Slave Study region. Final Report. Available from the West Kitikmeot Slave Study Society, P.O. Box 2572, Yellowknife, Northwest Territories X1A 2 P9.

MILLER, S.G., KNIGHT, R.L., and MILLER, C.K. 1998. Influence of recreational trails on breeding bird communities. Ecological Applications 8:162-169.

NATIONAL AUDUBON SOCIETY. 2004. The Christmas bird count historical results. http://www.audubon.org/bird/cbc. Accessed 30 August 2004.

NATIONAL RESEARCH COUNCIL. 2003. Cumulative environmental effects of oil and gas activities on Alaska's North Slope. Washington, D.C.: The National Academies Press.

REIJNEN, R., FOPPEN, R., TER BRAAK, C., and THISSEN, J. 1995. The effects of car traffic on breeding bird populations in woodland. III. Reduction in density in relation to the proximity of main roads. The Journal of Applied Ecology 32:187-202.

REIJNEN, R., FOPPEN, R., and MEEUWSEN, H. 1996. The effects of traffic on the density of breeding birds in Dutch agricultural grasslands. Biological Conservation 75:255-260.

RIFFELL, S.K., GUTZWILLER, K.J., and ANDERSON, S.H. 1996. Does repeated human intrusion cause cumulative declines in avian richness and abundance? Ecological Applications 6: $492-505$.

ROTTENBORN, S.C. 1999. Predicting the impacts of urbanization on riparian bird communities. Biological Conservation 88: 289-299.
SPATT, P.D., and MILLER, M.C. 1981. Growth conditions and vitality of sphagnum in a tundra community along the Alaska Pipeline haul road. Arctic 34(1):48-54.

STANIFORTH, R.J. 2002. Effects of urbanization on bird populations in the Canadian central Arctic. Arctic 55(1):87-93.

THORINGTON, K.K., and BOWMAN, R. 2003. Predation on artificial nests increases with human housing density in suburban habitats. Ecography 26:188 - 196.

TROY, D.M., and CARPENTER, T.A. 1990. The fate of birds displaced by the Prudhoe Bay oil field: The distribution of nesting birds before and after P-pad construction. Prepared by Troy Ecological Research Associates, for BP Exploration (Alaska) Inc., Anchorage, USA. Available from Troy Ecological Research Associates, 2322 E. 16th Ave., Anchorage, Alaska 99508.

TRUETT, J.C., SENNER, R.G.B., KERTELL, K., RODRIGUES, R., and POLLARD, R.H. 1994. Wildlife response to small-scale disturbances in arctic tundra. Wildlife Society Bulletin 22: $317-324$.

TRZCINSKI, M.K., FAHRIG, L., and MERRIAM, G. 1999. Independent effects of forest cover and fragmentation on the distribution of forest breeding birds. Ecological Applications 9:586-593.

VAN DER ZANDE, A.N., TER KEURS, J., and VAN DER WEIJDEN, W. 1980. The impact of roads on the densities of four bird species in an open field habitat: Evidence of a long distance effect. Biological Conservation 18:299-321.

VAN HORNE, B. 1983. Density as a misleading indicator of habitat quality. Journal of Wildlife Management 47:893-901.

WALKER, D.A., and EVERETT, K.R. 1987. Road dust and its environmental impact on Alaskan taiga and tundra. Arctic and Alpine Research 19:479-489. 